\title{
The Contributions of Regional Knowledge Networks Researching Environmental Changes in Latin America and Africa: a Synthesis of what they can do and why they can be policy relevant
}

\author{
$\underline{\text { Myanna Lahsen }}^{1}, \underline{\text { Mercedes M. C. Bustamante }}^{2}$, Robert Swap $^{3}, \underline{\text { Elizabeth McNie }}^{4}, \underline{\text { Jean P. H. B. Ometto }}^{1}, \underline{\text { Tatiana Schor }}^{5}$,

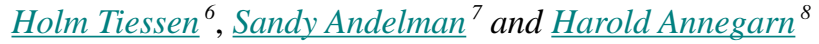

\begin{abstract}
We provide a synthesis of what regional scientific research networks in less developed regions of the world can do and why they might be relevant for societal decisions and practice. We do so through a focus on three regional science network initiatives that aim to enhance understanding of the multiscalar dynamics of global environmental change (GEC) regionally and globally, namely the Southern Africa Regional Science Initiative (SAFARI 2000), the Large-Scale BiosphereAtmosphere Experiment in Amazonia (LBA), and the Inter-American Institute for Global Change (IAI). With a view to aiding future efforts at regional research network formation, we assess whether and how these three networks enhanced regional science, and the extent to which they sought and managed to bridge the science-policy gap that challenges GEC science as a whole. Identifying key decisions and attributes bearing on their successes, the analysis attends specifically to how the three networks sought to build capacity, how differences and similarities between them affected their level of autonomy from governments, and how this and other factors influenced their functioning and achievements.
\end{abstract}

Key Words: Africa; capacity building; global change; Latin America; scientific research networks

\section{INTRODUCTION}

Because of the interplay between broad-scale and fine-scale patterns and processes in ecological and social systems (Huston 1999, Rodó et al. 2002, King et al. 2004), science aiming to address the obstacles to environmental sustainability in a comprehensive and holistic manner must be multiscalar, integrated, interdisciplinary, and neither global nor entirely local, but a combination of the two (Huston 1999, Cash et al. 2003, Clark and Dickson 2003, Gallopin 2004, King et al. 2004, Seabury 2004, van Kerkhoff and Lebel 2006, Misselhorne et al. 2012, Stafford-Smith et al. 2012). Moreover, meeting the deep challenge of environmental sustainability highlights the imperative to overcome collaborative barriers in science and governance (Hardin 1968, Ostrom et al. 1999, Dietz et al. 2003, Tomich et al. 2007, Bodin and Crona 2009). Aware of this, and to mobilize financial resources from multiple countries, scientists have formed networks to advance scientific understanding of complex nonlinear, cross-scale environmental dynamics. Such networks have especially flourished in recent decades. The compression of time and space resulting from new technologies enhancing mobility and communication, and expanding scientific capacity created conditions for the emergence of regional research networks (RRNs) around the world.

We provide a synthesis of what regional scientific research networks can do and why they might be relevant to societal decisions and practice. We do so through a focus on three regional-science network initiatives in the Americas and Africa that share the goal of enhancing understanding of interactions between environmental changes on regional and global scales: The Southern Africa Regional Science Initiative (SAFARI 2000), the Large-Scale Biosphere-Atmosphere Experiment in Amazonia (LBA), and the Inter-American Institute for Global Change (IAI). The three RRNs are all focused on regions with ecosystems and large populations that are vulnerable to various impacts of global environmental change (henceforth "GEC"), regions subsuming low- or middle-income countries aspiring to catch up with the level of development attained by the world's richer countries, often at the expense of environmental protection. Deficit at the levels of knowledge and action related to GEC are a global characteristic (Sagar and VanDeveer 2005), but it is especially marked in contexts of limited financial resources (Söderbaum 2001, Lahsen et al. 2010). Active and equal engagement in science and policy related to GEC is thus limited, especially in the case of low- and middle-income countries (Sagar and Kandlikar 1997, Miller 1998, Lahsen 2004, 2007, Dietz and Stern 2008), which in turn limits the trust and perceptions of salience needed to secure the engagement of the latter (Lahsen 2004, 2007, Mitchell et al. 2006), creating a vicious circle.

With view to aid future efforts at RRN formation, we compare the three RRNs, assessing whether and how they enhanced regional science, and identifying attributes that proved

\footnotetext{
${ }^{1}$ Instituto de Pesquisas Espaciais, ${ }^{2}$ Universidade de Brasília, ${ }^{3}$ University of Virginia, ${ }^{4}$ Department of Political Science, Purdue University, ${ }^{5}$ Universidade Federal do Amazonas, ${ }^{6}$ Inter-American Institute for Global Change Research, ${ }^{7}$ Conservation International, ${ }^{8}$ Department of Geography, Environmental Management and Energy Studies, University of Johannesburg, Auckland Park, South Africa
} 
relevant to their successes. The research attends to how they built capacity, how differences and similarities between them affected their autonomy from governments, and how this and other factors influenced their functioning and achievements.

We adopt a collective case study approach that, unlike theorybuilding, seeks to provide understanding of the nature, practices, and challenges of regional science networks (Stake 2000). Collectively, the authors are well suited to inform these case studies, having extensive experience as participants and leaders in the RRNs and as scholarly analysts of them. Data were collected using multiple methods over several years, including archival research, semistructured interviews, participant observation, and analysis of relevant policies.

\section{Introduction to the three regional research networks}

The IAI is an intergovernmental organization oriented toward the production of GEC science. Created in 1992 as an intergovernmental treaty organization, it now comprises 19 nations in the Americas. IAI sought to respond to the challenge of GEC in the Americas on the premise that doing so effectively requires governmental support and the development of active, transnational scientific networks. It was conceived to transcend the interests and capacities of any single government, and to overcome the inaction and lack of oversight and science-based planning that result when responses to global change rest entirely with individual national governments. The IAI issues calls for proposals, and funds research using peer review processes. By this mechanism, it promotes regional cooperation for interdisciplinary research on regional aspects of global changes related to the functioning of the biosphere, ocean, and atmosphere, with particular attention to impacts on ecosystems, biodiversity, and socioeconomic systems (for examples of research topics that IAI supports, see http://www. iai.int/). Representatives of participating governments meet annually and provide core funding, but are not otherwise involved in decisions on science projects. The formalized structures and government-independent peer review limits governments' ability to use funding practices to discourage politically inconvenient science; the IAI reserves rules of independence in research and funding decisions, although governments can veto unwanted research within their borders, a right no government yet has exercised.

The LBA was the largest international science program ever focused on the Amazon. It aimed to increase the understanding of the role of the Amazon in GEC, including consequences of tropical forest conversion, regrowth, and selective logging. Scientific activities under the LBA were at their height in the years 1998-2005. During this first, intense phase of its existence, the LBA was an international program cofunded primarily by the Brazilian government, the U.S. National Aeronautics Space Administration (NASA), and the European Union. Its scientific activities required the building of extensive infrastructure in numerous locations throughout the Amazon, including high towers, laboratories, and camps. After 2004, the LBA continued as a government-controlled, national program in which non-Brazilian scientists participated in more limited fashion and only upon formal, individualized invitation.

Established in 1998, SAFARI 2000 was a large-scale environmental and remote sensing initiative exploring the relationship of biogenic, pyrogenic, and anthropogenic aerosol and trace gas emissions and transports over the Southern African Development Community (SADC) region, which subsumes 12 countries, excluding Mauritius. The initiative was limited in time and scope to two intensive field observation periods in 2000 during the wet and the dry seasons, respectively (Otter et al. 2002, Swap et al. 2002, 2003, Shugart et al. 2004). It involved researchers from North America, Europe, Asia, and Africa. Without the benefit of large, dedicated funds, SAFARI 2000 drew support from existing projects and networks, such as the International GeosphereBiosphere Programme (IGBP) Kalahari Transect and the Miombo Network. It invited researchers to bring their own resources to the project, conceptualizing contributions broadly as including time and commitment, personnel, granting access to research sites and data, and hosting scientists. This broad definition of contributions maximized inclusion of participants with equity in the program. Adopting a flat management structure that included a small, five-member executive committee, overhead costs and bureaucracy were minimized. In the absence of a centralized administrative project office, the success of SAFARI 2000 depended on a self-administered network in which participating scientists convened and led meetings and data workshops.

The above descriptions reveal that the three regional initiatives have features common to RRNs in general (Söderbaum 2001). They were multifunctional, adopting a number of different aims and activities: they focused on research production, research networking, and education and training, working to collect, standardize, and freely share environmental data and knowledge; they awarded grants, supported publications, and disseminated information freely beyond the network. The three RRNs in focus shared their specialization in the production of science related to transboundary environmental phenomena driven by locally generated questions and led by local expertise, in ways that avoided past patterns of Northern dominance in defining the science agenda and associated benefits.

\section{CAPACITY BUILDING}

During the latter decades of the 20th century, a number of regional scale environmental science campaigns took place in Africa and Latin America, driven by questions generated by scientists from outside the regions (see Harriss et al. 1988, 1990, Andreae et al. 1996). By contrast, SAFARI 2000, LBA, 
and the IAI sought to include in-region scientists in leadership roles at all stages, using networking and funds to reduce the isolation of global change scientists from smaller countries where there are few, if any, other scientists working on global change issues. In such countries, national resources for research are limited or nonexistent.

Researchers from smaller and less wealthy countries benefit from participating in the three RRNs: they learn from, and contribute to, the production of multiscalar knowledge, gain access to extranational funding sources, and achieve greater voice nationally and internationally, which can be used to press for additional resources and for international science agendas attuned to their local circumstances. In these ways, RRNs can enhance the quality of GEC research, which has tended to be dominated by wealthy country scientists (Sagar and Kandlikar 1997, Miller 1998, Lahsen 2004, 2007). This enables low- and middle-income country leaders to gauge their own environmental challenges and equips them to participate more effectively in international policy processes (for a definition of low- and middle-income countries, see Lahsen et al. 2010.).

\section{Inter-American Institute for Global Change}

The IAI has created and used regional networks to supplement and expand otherwise fragmented, uneven national research, transcend political divides, and reduce mistrust among nations that previously had limited joint environmental research and policy. IAI's directorate fostered research projects in countries with weak scientific communities, by linking them with leading scientists from wealthier countries in the Americas, to develop new scientific capacity and knowledge about environmental processes in countries that have been relatively less researched because of national underfunding. An independent review of the IAI concluded that its greatest contribution was its success in building scientific capacity and networks throughout the Americas (Melillo et al. 2007).

Scientific collaboration on the north-south axis was especially strong in the early stages of the IAI when most principal investigators were North American. Southern principal investigators grew in number, in step with the enhancement of regional research capacity. Eighty percent of the IAI's funded projects are now led by scientists from Latin America (Swap 2008). North-south collaboration within the IAI network continues to be important because of the geographically specific scientific knowledge that northern scientists have developed about environmental systems, and also because they can provide access to resources and expensive technologies. Increasing southern leadership of networks has resulted in greater attention to equity issues in GEC research.

\section{Large-Scale Biosphere-Atmosphere Experiment in Amazonia}

Moving the LBA's headquarters from the developed southern Brazil to the Amazon in 2003 symbolized an effort to avoid past structures of dominance; the more developed southern Brazil has been, and to some extent still is, guilty of patterns of scientific exploitation and dominance, similar to those associated with so-called scientific colonialism at the international level. These practices include relegating local researchers to inferior functions, extracting and using data without acknowledging researchers from the poorer northern region as equal collaborators and coauthors.

Brazilian law requires that Brazilian scientists serve as principal coinvestigators in international scientific projects on Brazilian soil. Supported by non-Brazilian counterparts, Brazilian LBA architects, all participating scientists, insisted that the law be observed not only on paper but in spirit. Although the LBA reflected some geopolitical fissures (Lahsen 2009), in many cases participation encouraged the formation of strong collaborative relations between Brazilian scientists and their American and European counterparts, collaborations that continued after 2004 under the aegis of new research programs and projects.

Training and education of students and young scientists are recognized as one of the main outcomes and legacies of the LBA program (Table 1). Key enabling factors were the creation of research towers, in situ laboratories, and other physical infrastructure for scientific activities; the establishment of a network of local researchers and institutions closely interconnected with highly qualified foreign scientists who came to do research with scientists in Brazil; and the Brazilian government's willingness to fund the initiative after the international agreement with NASA ended in 2004. The Brazilian government took important steps to retain and strengthen the scientific talent nationally and in the Amazon region post-2004, providing considerable funding for research and higher education institutions in the Amazon closely linked to the LBA (e.g., the Federal University of Western Pará in Santarém, UFOPA).

\section{Southern Africa Regional Science Initiative 2000}

From the first concept formulation of SAFARI 2000, southern African scientists were involved in partnership with U.S. scientists in a context of clearly established principles of capacity recognition, reciprocal academic exchanges of students, and alternation of major planning and science meetings between Africa and the USA. Existing regional capacity was recognized and enhanced through recruitment of young professionals from less resourced research institutions and through support enabling young African researchers to visit research institutions in southern Africa, Europe, and the United States.

Capacity to execute major science campaigns was enhanced through deliberate staging of science planning meetings open to all. The meetings alternated between better-resourced partners such as the U.S. and South Africa, and partner countries such as Botswana, Zambia, and Mozambique, 
Table 1. Summary of main characteristics of the three regional networks: Inter-American Institute for Global Change (IAI), Southern Africa Regional Science Initiative 2000 (SAFARI 2000), and Large-Scale Biosphere-Atmosphere Experiment in Amazonia (LBA).

\begin{tabular}{|c|c|c|c|c|c|}
\hline Program & $\begin{array}{l}\text { Central Science } \\
\text { Problem and } \\
\text { Regional Coverage } \\
\end{array}$ & Primary Participants & Capacity Building & Policy Influence & $\begin{array}{l}\text { Organizational } \\
\text { Structure and } \\
\text { Institutions } \\
\end{array}$ \\
\hline $\begin{array}{l}\text { IAI } \\
\text { 1992-present }\end{array}$ & $\begin{array}{l}\text { Global environmental } \\
\text { change impacts on } \\
\text { ecosystems, } \\
\text { biodiversity, and } \\
\text { socioeconomic } \\
\text { systems; economic } \\
\text { aspects of climate } \\
\text { change mitigation and } \\
\text { adaptation. } \\
\text { North, Central, and } \\
\text { South Americas. }\end{array}$ & $\begin{array}{l}\text { Originally just } 16 \\
\text { countries, now } 19 \\
\text { countries of the } \\
\text { Americas: Argentina, } \\
\text { Bolivia, Brazil, } \\
\text { Canada, Chile, } \\
\text { Colombia, Costa } \\
\text { Rica, Cuba, } \\
\text { Dominican Republic, } \\
\text { Ecuador, Guatemala, } \\
\text { Jamaica, Mexico, } \\
\text { Panama, Paraguay, } \\
\text { Peru, Uruguay, } \\
\text { United States, } \\
\text { Venezuela. } \\
\text { Multinational and } \\
\text { multidisciplinary } \\
\text { teams of scientists } \\
\text { including physical, } \\
\text { natural, and social } \\
\text { scientists. }\end{array}$ & $\begin{array}{l}\text { Made significant } \\
\text { contributions in } \\
\text { building research } \\
\text { capacity and } \\
\text { networks throughout } \\
\text { the Americas. Strong } \\
\text { support for South- } \\
\text { South research } \\
\text { collaboration. }\end{array}$ & $\begin{array}{l}\text { Use of some outputs } \\
\text { in various laws and } \\
\text { climate-change } \\
\text { strategies. Promotion } \\
\text { of policy dialogues. } \\
\text { Implementation of } \\
\text { 'training institutes' to } \\
\text { actively link } \\
\text { researchers, } \\
\text { practitioners, and } \\
\text { other stakeholders to } \\
\text { identify policy- } \\
\text { relevant research } \\
\text { needs and stimulate } \\
\text { such research. }\end{array}$ & $\begin{array}{l}\text { IAI Directorate } \\
\text { operates } \\
\text { independently. Fairly } \\
\text { bureaucratic and } \\
\text { hierarchical, with } \\
\text { strong centralized } \\
\text { structure and formal } \\
\text { hierarchy. Location } \\
\text { between various } \\
\text { governments and } \\
\text { researchers created a } \\
\text { buffer that insulated } \\
\text { research activities } \\
\text { from political or } \\
\text { economic influence. } \\
\text { Funding: National } \\
\text { contributions. }\end{array}$ \\
\hline $\begin{array}{l}\text { SAFARI } 2000 \\
1999-2001\end{array}$ & $\begin{array}{l}\text { Linkages between } \\
\text { land and atmosphere } \\
\text { processes; } \\
\text { relationship of } \\
\text { biogenic, pyrogenic, } \\
\text { and anthropogenic } \\
\text { aerosol and trace gas } \\
\text { emissions and } \\
\text { transports over the } \\
\text { Southern African } \\
\text { Development } \\
\text { Community. }\end{array}$ & $\begin{array}{l}\text { Australia, Belgium, } \\
\text { Botswana, Canada, } \\
\text { France, Germany, } \\
\text { Mozambique, } \\
\text { Namibia, Portugal, } \\
\text { South Africa, } \\
\text { Sweden, United } \\
\text { Kingdom, United } \\
\text { States, Zambia, } \\
\text { Zimbabwe. }\end{array}$ & $\begin{array}{l}\text { Improvement of } \\
\text { communication } \\
\text { between scientists } \\
\text { across institutions } \\
\text { and nations. } \\
\text { Developed } \\
\text { consortium of } \\
\text { institutions of higher } \\
\text { learning. Graduate- } \\
\text { student researchers } \\
\text { participated in the } \\
\text { UN Framework } \\
\text { Convention on } \\
\text { Climate Change in } \\
\text { Copenhagen. }\end{array}$ & $\begin{array}{l}\text { "Maputo Declaration } \\
\text { on the Prevention and } \\
\text { Control of Air } \\
\text { Pollution in Southern } \\
\text { Africa and its likely } \\
\text { Transboundary } \\
\text { Effects" }\end{array}$ & $\begin{array}{l}\text { Flat, decentralized, and } \\
\text { relatively autonomous } \\
\text { and driven by specific } \\
\text { research questions and } \\
\text { needs. } \\
\text { Funding: Leveraged } \\
\text { informal and formal } \\
\text { support from U.S. } \\
\text { NASA, international } \\
\text { community, various } \\
\text { southern African } \\
\text { Nations }\end{array}$ \\
\hline $\begin{array}{l}\text { LBA - Phase I: } \\
\text { 1996-2005 }\end{array}$ & $\begin{array}{l}\text { Sustainable land use } \\
\text { in Amazonia; } \\
\text { understanding the } \\
\text { role of the Amazon } \\
\text { and deforestation in } \\
\text { global environmental } \\
\text { change. } \\
\text { Amazon Basin/ } \\
\text { transition Amazon to } \\
\text { Cerrado (Brazil). }\end{array}$ & $\begin{array}{l}\text { Phase I: Brazilian } \\
\text { research institutes and } \\
\text { universities, Peru, } \\
\text { Ecuador, Bolivia, } \\
\text { Venezuela, } \\
\text { Colombia, United } \\
\text { States, United } \\
\text { Kingdom, Germany. } \\
\text { Mostly physical and } \\
\text { natural scientists. }\end{array}$ & $\begin{array}{l}\text { Law requires } \\
\text { international research } \\
\text { located in Brazil be } \\
\text { led by Brazilian Co- } \\
\text { Principal } \\
\text { Investigators. }\end{array}$ & $\begin{array}{l}\text { Limited policy- } \\
\text { relevant outputs. As } \\
\text { program matured } \\
\text { researchers sought to } \\
\text { inform research with } \\
\text { more input from } \\
\text { stakeholders. }\end{array}$ & $\begin{array}{l}\text { Evolved from flat, } \\
\text { decentralized } \\
\text { organization with } \\
\text { scientist-led, bottom- } \\
\text { up initiative, becoming } \\
\text { more bureaucratic as } \\
\text { resources were needed } \\
\text { and leveraged. } \\
\text { Funding: NASA and } \\
\text { Brazil }\end{array}$ \\
\hline $\begin{array}{l}\text { LBA - Phase II: } \\
\text { 2005-present }\end{array}$ & & $\begin{array}{l}\text { Phase II: Mainly } \\
\text { Brazil. Primarily } \\
\text { physical and natural } \\
\text { scientists. }\end{array}$ & & & \\
\hline
\end{tabular}


facilitating participation by a broader range of local academics, students, and government dignitaries, as well as members of the media. This served science communication locally and science diplomacy among nations (Annegarn and Swap 2012). SAFARI 2000 science teams performed extensive educational outreach to the public in both urban and remote locations (Annegarn et al. 2002), attracting more than 10,000 scholars and members of the public to an open house event prior to the launch of its field campaign. Such outreach provided transparency and reduced distrust and local resistance to the campaign.

The efforts to enhance intellectual capacity carried on beyond the life of the intensive observation and data synthesis phases. A legacy activity is the Eastern and Southern African Virginia Networks and Associations (ESAVANA) consortium, an annual program that brings together U.S. and African university students and researchers to perform applied research and outreach in Africa. Initially focused on natural science and regional environmental issues, ESAVANA research has since expanded to include projects on public policy and health. ESAVANA has persisted for nine years.

\section{POLICY INFLUENCE}

As is common for RRNs (Söderbaum 2001), the three RRNs studied here have sought to influence policy formulation, cognizant of the need for stronger linkages between science and decision making relating to complex-coupled humanenvironmental systems (Gallopín 2004, McNie 2007, Reid et al. 2009, Rockström et al. 2009). Policy impact is difficult to achieve in practice and remains a challenge for GEC science as a whole. ${ }^{[1]}$

\section{Inter-American Institute for Global Change}

The American Association for the Advancement of Science 2007 review of the IAI concluded that research outputs had not been sufficiently translated into policy-relevant discourse and action, and that this reflected a lack of information concerning policy makers' needs and insufficient consideration of social aspects of GEC (Melillo et al. 2007). The IAI subsequently created training institutes to bring researchers and practitioners together to explore information needs, and to stimulate the inclination of researchers to meet those needs. Such efforts have yielded results but remain circumscribed by academic incentive structures favoring scientific publications and innovative science over problemdriven practical research with societal benefits. IAI sought to involve the social sciences, creating a separate call for social science proposals. To foster integration and "stretching" by both sides of the "cultural divide" (Snow 1964), IAI proceeded by first infusing incoming social science research into natural science projects, and later created programs with joint proposal development. This exercise revealed that social-natural transdisciplinary science remains an area in need of development.
The IAI leadership learned that collaborations involving multinational research teams had the unexpected effect of stimulating natural scientists' curiosity in how differences in socio-cultural and political realities shape environmental processes and policy, leading some to initiate collaboration with social scientists to investigate related dynamics.

Examples of policy impacts from IAI-funded science include (1) the use of remote sensing data, generated by IAI projects, as a legal basis for land-use decisions and dispute resolution in Costa Rica; (2) the incorporation of findings from a forest and watershed project in Chile's new forestry law; (3) the inclusion of biodiversity in Colombia's national climate change strategy; (4) the use of ecological expertise in decisions on forest conservation at State (Brazil) and provincial (Argentina) levels; and (5) the use of air quality data in several municipal emission control programs. Thus IAI science output informed national policies, legislation, and local environmental management at national, provincial/state, and municipal levels.

\section{Large-Scale Biosphere-Atmosphere Experiment in Amazonia}

Originally, the LBA was centrally propelled by scientific curiosity rather than environmental concerns. At the time, information for decision making was a less common discourse than it later became. A rationale for the LBA was that the science was useful for international climate negotiations and for improving land-use decisions impacting the Amazon, but LBA architects did little analysis of local and regional stakeholder needs and perceptions from the initial stages of program definition, limiting the usefulness of the science for the purpose of improving regional resource management (Lahsen and Nobre 2007).

Distrust nearly killed the LBA in the planning stages because powerful parts of the Brazilian federal government did not want to authorize it (Lahsen 2008), evoking long-standing discourses about environmentalism as a foreign plot to undermine Brazil's national sovereignty, development, and geopolitical ambitions premised on unrestrained exploration of the Amazon's natural resources. Similarly, in 1999, a group of elected politicians brought a lawsuit against Brazilian officials who had approved the LBA, including the thenPresident Fernando Henrique Cardoso. The group charged that the project threatened national sovereignty. They feared that data collected by means of aircraft and satellites could lead to foreign discovery and exploitation of gold and other natural resources, and that biological data would be stolen and used to develop pharmaceuticals for foreign profit ("biopiracy"). Such distrust is a wider phenomenon in Brazil and has foundation in real events (Prado 2003). There are no indications that they were well-founded in the case of the LBA, to the contrary. Nevertheless, suspicions were allowed to flourish because the LBA initial leaders ignored the 
importance of transparency and accountability to local populations and to Brazilian governmental authorities at various scales, partly because NASA was unused to on-theground campaigns in a foreign, less developed country setting. In 2003, negative local and national reactions to the strong foreign presence and NASA's headquarters in Santarém, Pará, required high-level diplomatic interactions between U.S. and Brazilian diplomats to de-escalate the geopolitically charged tensions.

These politics and national sovereignty concerns prompted the Brazilian government to generally control the program, culminating in its relative nationalization post-2004. Already during the first phase, the Brazilian government used its political power to veto certain studies under the LBA that might yield analyses critical of national natural resource management. This weakened the development of social science investigations under the LBA (Schor 2008). Opposition to the LBA within parts of the federal government only abated after years of effort to improve local integration and communication, after the Brazilian government had assumed control over the program.

During the second phase, greater effort was also made to tailor the science agenda to the expressed needs of decision makers and local and regional environmental nongovernmental organizations, resulting in research on climatic and hydrological variability and dynamics, and on the transformation of the Amazonian environment, including the sustainability of environmental services and systems of terrestrial and aquatic production (Batistella et al. 2009). A sign of the improved authority of the LBA in the eyes of Brazilian authorities was the 2007 law (n. 93/2007) in Amazonas to create and regulate policies addressing climate change, environmental conservation, and sustainable development. This law was also a positive consequence of the decision to transfer the LBA's headquarters from the rich and dominant state of São Paulo to Amazonas.

The LBA remains concentrated on natural science questions. However, in 2013, the strongly LBA-connected Universidade Federal do Oeste do Pará begins a doctoral program in Society, Nature and Development that aims to develop more social science, also in projects under the LBA.

\section{Southern Africa Regional Science Initiative 2000}

SAFARI 2000 institutionalized mechanisms that stimulated consideration and communication of the campaigns' potential policy implications, including combating regional transboundary air pollution, improving crop yields and providing real time wild-fire warnings. To produce science outcomes relevant to the needs of the region, SAFARI 2000 provided support for research, education, and public outreach to governments, NGOs, and scientific networks. These networks in turn used their new resources, i.e., data, as well as human and social capital, to influence local and regional environmental decision making. The 2003 Regional Policy Dialogue on Air Pollution drew heavily on the use of scientific observations from SAFARI 2000 and involved ministers and top ranking governmental officials from seven Southern African Development Community (SADC) countries. The major outcome was a draft SADC policy declaration entitled "The Maputo Declaration on the Prevention and Control of Air Pollution in Southern Africa and its Likely Transboundary Effects."

\section{ORGANIZATIONAL AND INSTITUTIONAL STRUCTURE}

RRNs can have a wide variety of attributes and vary significantly (Söderbaum 2001, Hettne and Söderbaum 2006) in their levels of formality and bureaucracy; some are hierarchical, whereas others are very decentralized, loosely affiliated networks (Söderbaum 2001, Hettne and Söderbaum 2006). Söderbaum identifies four types of regional networks. Regional Research Centers (RRCs) tend to be formally structured and hierarchical networks, with strong ties and lines of accountability to external actors such as donors and governments. They are usually large, well-funded, and comprehensive in their activities. Examples include the International Livestock Research Institute and West Africa Rice Development Association. By contrast, Regional Research Programs or Projects (RRPs) are informal, nonhierarchical, and decentralized in management and operations, with fewer lines of accountability to governmental actors. They tend to be small, and to emphasize networkbuilding and education over research (Hettne and Söderbaum 2006). These two types occupy opposite ends of the spectrum from more to less structured, with Regional Research Organizations (RROs) and Regional Research Associations (RRAs) located in between, in this order.

The IAI strongly resembles the RRC type. Formalized structure and processes are needed because of the large number of national governments, agencies, and scientists involved, including the need to secure funding and governmental permissions to realize its ambitious goals. High-level political support and organization, centralized coordination, and a dedicated staff are essential for sound environmental management and research that involves coordinating, collecting, and integrating results from multiple countries. The downside is that these organizational features called for a multilateral agreement, a very complex instrument that requires large amounts of time, and of human and financial resources.

Resembling a RPP, the LBA began as a loosely structured, scientist-led initiative. However, the need for massive funding, the transnational nature of the scientific operations in the Amazon basin, the involvement of NASA and use of technologies such as remote sensing and surveillance aircraft, rendered a more formal structure unavoidable, as did Brazilian 
sensitivities related to the Amazon. LBA architects sought to avoid the complexity of a multilateral agreement as a basis for its establishment. Thus, the U.S. and Europe pursued separate bilateral agreements with the Brazilian government. A downside of this solution was that it gave considerable control to the Brazilian government, subjecting the science agenda to sovereign concerns and conceptions of national interests that sometimes conflicted with the scientific agenda, limiting some lines of research. These circumstances placed the LBA in between the RRCs and RRPs, with a profile more consistent with Regional Research Organizations.

SAFARI 2000's informal structure, flat hierarchy, and decentralized decision making processes are consistent with RRPs. SAFARI 2000's limited three-year life-span for field operations and existing national and regional science networks reduced the need for more formal structures. Moreover, its leveraging of research funds from the private sector reduced its direct dependence on government funding and, thus, control. Similar to the LBA in Brazil, SAFARI 2000 raised fears among some African politicians that the activities might result in regional disadvantage in future climate negotiations and that the use of U.S. surveillance aircrafts for data collection might undermine national interests and security. However, no tangible limitations were imposed on the campaign by the politicians, and the suspicions appeared to subside, perhaps because of well-executed outreach efforts, in particular with the South African Air Force.

\section{CONCLUSION}

The above analyses suggest that all three RRNs made significant contributions to the enhancement of regional science, and that each achieved some policy successes. By avoiding scientific colonialism and taking efforts to conduct societally relevant research and build capacity, the three RRNs were able to build sufficient trust between policy makers and scientists to secure a few important policy advances. Nevertheless, producing useful knowledge is a continuing challenge for the three RRNs, as for GEC research as a whole. Greater integration of social science and stimulating the curiosity of natural scientists about social and governance dimensions of the phenomena they study can facilitate the production of more policy relevant and impactful knowledge.

Finding a proper balance between the number and capacity of researchers from the north and the south is important to the success of a RRN. Avoiding the traditional northern dominance and scientific colonialism, while maintaining important involvement of scientists from high-income countries, these three RRNs avoided painful mistakes of other initiatives ${ }^{[2]}$ Supporting south-south research collaboration is important, and IAI research agendas are driven largely by researchers from Latin America rather than North America. However, the north-south dimension of the RRN is also necessary to encompass important sources of scientific innovation and access to some forms of know-how and to high technology resources, such as satellite imagery.

In his typology and theorizing of RRNs, based on cases in Africa, Frederik Söderbaum (2001:154) writes that "most RRNs appear to enjoy a relatively high degree of autonomy in relation to external actors, such as national governments and donors." His explicitly tentative proposition applies best to the RRN in Africa, and poorly to the Latin America-focused IAI and LBA. Whether this reflects broad differences between tendencies of RRNs in Africa versus Latin America is uncertain. Decision makers in Brazil and in southern Africa expressed similar national security concerns about the LBA and SAFARI 2000. However, in the latter case, these subsided. It is unclear whether this is a reflection of differences at the levels of the nature of the governments (e.g., differences in the extent to which governments in the two regions were motivated or able to oppose the science projects) and/or the RRNs (e.g., level and success of outreach efforts), or entirely due to other factors.

Networks may commonly be associated with informal, decentralized, and horizontal structures, and tend to be cooperative and egalitarian rather than hierarchical and competition-oriented. However, multi- or transnational GEC research is expensive and requires governmental permissions, and this propelled the organization of these RRNs toward formality, bureaucracy, and hierarchy.

SAFARI 2000 was a natural science experiment limited to two field campaigns. By force of its relatively short lifespan, SAFARI 2000 did not have the benefit of adjusting its practices in the course of its existence, in contrast to the IAI and LBA, both of which had time to reflect and alter their practices with regard to such things as the inclusion of social sciences to achieve greater policy relevance. However, subsequent initiatives, such as ESAVANA, have ventured toward greater inclusion of social science and policy research, and to that extent the move in that direction is a trajectory detectable in all three RRNs.

Like SAFARI, IAI and LBA started out concentrating on natural science. Their different relations to governments were consequential in this respect. Bolstered by its intergovernmental mandate to also fund social science, the IAI was most inclined and most able to stretch to include social science, and it did so in a way specifically designed to enhance its integration with natural science and its policy impact. Formally limited by the Brazilian government to fund and integrate "human dimensions" research in its early stage, the LBA is only now beginning to reignite such research. Although the IAI enjoys some independence in its science funding decisions, governments centrally affect its functioning and can impose tangible limits to its scientific production and policy impact. As for the more hierarchical structure and multilateral nature of the IAI, it also comes with a strong degree of high level 
politics, albeit less centrally controlled by any single government and restrained in a more formal manner by a statute.

Of the three RRNs analyzed here, SAFARI 2000 was most removed from government interference. This was partly because it maintained a loose, nonhierarchical structure and sought to harness existing funds and initiatives to its science plan, rather than raising new funds and an elaborate bureaucratic structure. There were, briefly, governmental suspicions of SAFARI 2000 and discussions about shutting down the campaign, which were successfully allayed through high-level engagement between project leaders and politicians. In terms of policy influence, the major tangible outcome was the Maputo Declaration on Transboundary Air Pollution. As shown in research on the policy uptake of LBA science in Brazil (Lahsen 2007, 2009), politics can drive science and limit its influence in policy processes when decision makers are suspicious of international science initiatives and, even toward participating national scientists. Despite their profound consequences for the uptake of scientific knowledge, suspicions and other intersubjective perceptions tend to be insufficiently recognized and investigated, precisely a kind of research that can identify causes of knowledge-action gaps.

The case studies show that context matters, therefore cultural and political factors need to be carefully evaluated along with scientific goals when designing a RRN. To inform evaluations of the likely benefits and trade-offs tied to research network design decisions, additional research is needed to test when, where, and how different models and submodels work best, and under what circumstances. The present analysis suggests that the informal, nonhierarchical, and decentralized management that characterize the SAFARI model may be a good option when the goal is to do short-lived scientific campaigns focused on discrete, well-defined, and politically modestly "charged" problems such as transboundary air pollution; the policy ramifications of the anticipated findings related to transboundary air pollution were fairly predefined and limited to a declaration. Moreover, the problem is anchored in a specific region as are the solutions and their beneficiaries. A flat organizational structure is appropriate in such contexts and helps limit operational costs and governmental involvement that may unnecessarily limit and slow the science.

When the goal is to produce research on a longer-scale and with a less predelimited focus on "wicked" and politically sensitive topics related to climate change and natural resource use, other, more hierarchical and formalized structures may be necessary and desirable. The LBA and IAI offer different models and lessons in this regard. Both are able to develop agendas with the benefit of time, trial and error, and central control of considerable financial resources. These features allow learning that can yield improvements in management and strategies to overcome political resistances and enable careful design and experimentation with new forums to improve interaction among scientists and between scientists and decision makers. Especially strong in this regard, the IAI model may have the greatest potential to engender deeper institutional changes in favor of more policy-relevant science, an important attribute given that policy impact is a continued challenge for RRNs and for global change science as a whole. ${ }^{[1]}$ See http://www.icsu.org/search?Subject\%3Alist=Reviews, and for instance, the review of the International Geosphere Biosphere Programme (http://www.icsu.org/publications/ reports-and-reviews/igbp-review/review-of-the-internationalgeosphere-biosphere-programme-2009), which considers it "a matter of urgency" to identify ways to "maximize the scientific, policy, and practice impact s of IGBP-related science." See also Reid et al. 2009, which seeks to find paths to improved policy impact.

${ }^{[2]}$ For instance, in an effort to generate developing countrydefined, demand-driven, and problem-based research, the Dutch Ministry for Development Cooperation gave southern collaborators ownership over the research agenda and its execution over a period of over a decade, discouraging interaction with Dutch and other developed country researchers. It later realized that this strategy did not develop the desired southern agenda because the developing country researchers failed to reach agreement about research and priorities, i.e., the assumed southern unity and dialogue was missing, and because their southern researchers' sole leadership was incompatible with their limited infrastructure and research capacity (Koenders 2009).

Responses to this article can be read online at: http://www.ecologyandsociety.org/issues/responses. $\mathrm{php} / 5614$

\section{Acknowledgments:}

This work is a synthesis of presentations and discussions during the special session "Regional knowledge networks" jointly organized by the IAI and the International GeosphereBiosphere Programme (Brazilian regional office) during the 4th IGBP Science Conference held at the Cape Town International Convention Center, 5-9 May 2008.

\section{LITERATURE CITED}

Andreae, M. O., J. Fishman, and J. Lindesay. 1996. The Southern Tropical Atlantic Region Experiment (STARE): transport and atmospheric chemistry near the Equator-Atlantic (TRACE A) and Southern African Fire-Atmosphere Research Initiative (SAFARI): an introduction. Journal of Geophysical 
Research 101(D19):23519-23520. http://dx.doi. org/10.1029/96JD01786

Annegarn, H. J., L. Otter, R. J. Swap, and R. J. Scholes. 2002. Southern Africa's ecosystem in a test-tube - a perspective on the Southern African Regional Science Initiative (SAFARI 2000). South African Journal of Science 98:111-113.

Annegarn H. J., and R. J. Swap. 2012. SAFARI 2000: a Southern African example of science diplomacy in practice. Science and Diplomacy December:47-69.

Batistella, M., P. Artaxo, C. Nobre, M. Bustamante, and F. Luizão. 2009. Results from LBA and a vision for future Amazonian research. Pages 555-564 in M. Keller, M. Bustamante, J. Gash, and P. S. Dias, editors. Amazonia and global change. American Geophysical Union, Geophysical Monograph Series, Vol. 186, Washington, D.C., USA. http:// dx.doi.org/10.1029/2009GM000904

Bodin, Ö., and B. I. Crona. 2009. The role of social networks in natural resource governance: what relational patterns make a difference? Global Environmental Change 19:366-374. http://dx.doi.org/10.1016/j.gloenvcha.2009.05.002

Cash, D. W., W. C. Clark, F. Alcock, N. M. Dickson, N. Eckley, D. H. Guston, J. Jäger, and R. B. Mitchell. 2003. Knowledge systems for sustainable development. Proceedings of the National Academy of Sciences 100:8086-8091. http:// dx.doi.org/10.1073/pnas.1231332100

Clark, W. C., and N. M. Dickson. 2003. Sustainability science: the emerging research program. Proceedings of the National Academy of Sciences 100(14):8059-8061. http://dx.doi. org/10.1073/pnas.1231333100

Dietz, T., E. Ostrom, and P. Stern. 2003. The struggle to govern the commons. Science 302:1907-1912. http://dx.doi. org/10.1126/science.1091015

Dietz, T., and P. C. Stern, editors. 2008. Public participation in environmental assessment and decision making. Committee on the Human Dimensions of Global Change, Division of Behavioral and Social Sciences and Education, National Research Council, National Academies Press, Washington, D. C., USA.

Gallopín, G. C. 2004. What kind of system of science (and technology) is needed to support the quest for sustainable development? Pages 367-386 in H. J. Schellnhuber, P. J. Crutzen, W. C. Clark, M. Claussen, and H. Held, editors. Earth system analysis for sustainability. MIT Press, Cambridge, Massachusetts, USA.

Hardin, G. 1968. The tragedy of the commons. Science 162:1243-1248. http://dx.doi.org/10.1126/science.162.3859.1243

Harriss, R. C., M. Garstang, S. C. Wofsy, S. M. Beck, R. J. Bendura, J. R. B. Coelho, J. W. Drewry, J. M. Hoell Jr., P. A. Matson, R. J. McNeal, L. C. B. Molion, R. L. Navarro, V.
Rabine, and R. L. Snell. 1990. The Amazon Boundary Layer Experiment: wet season 1987. Journal of Geophysical Research 95(D10):16721-16736. http://dx.doi.org/10.1029/ JD095iD10p16721

Harriss, R. C., S. C. Wofsy, M. Garstang, E. V. Browell, L. C. B. Molion, R. J. McNeal, J. M. Hoell Jr., R. J. Bendura, S. M. Beck, R. L. Navarro, J. T. Riley, and R. L. Snell. 1988. The Amazon Boundary Layer Experiment (ABLE 2A): dry season 1985. Journal of Geophysical Research 93 (D2):1351-1360. http://dx.doi.org/10.1029/JD093iD02p01351

Hettne, B., and F. Söderbaum. 2006. Regional cooperation: a tool for addressing regional and global challenges. Pages 179-244 in Meeting global challenges: international cooperation in the national interest. Final report. International Task Force on Global Public Goods, Stockholm, Sweden.

Huston, M. A. 1999. Local processes and regional patterns: appropriate scales for understanding variation in the diversity of plants and animals. Oikos 86:393-401. http://dx.doi. org/10.2307/3546645

King, R. S., C. J. Richardson, D. L. Urban, and E. A. Romanowicz. 2004. Spatial dependency of vegetationenvironment linkages in an anthropogenically influenced wetland ecosystem. Ecosystems 7:75-97. http://dx.doi. org/10.1007/s10021-003-0210-4

Koenders, B. 2009. Strengthening the capacity of innovation systems. Pages 273-282 in H. Molenaar, L. Box, and R. Engelhard, editors. Knowledge on the move: emerging agendas for development-oriented research. International Development Publications, Leiden, The Netherlands.

Lahsen, M. 2004. Transnational locals: Brazilian experiences in the climate regime. Pages 151-172 in S. Jasanoff, and M. L. Martello, editors. Earthly politics, worldly knowledge: local and global in environmental politics. MIT Press, Cambridge, Massachusetts, USA.

Lahsen, M. 2007. Distrust and participation in international science and environmental decision making: knowledge gaps to overcome. Pages 173-196 in M. Pettinger, editor. The social construction of climate change. Ashgate, Aldershot, UK.

Lahsen, M. 2008. Large-scale biosphere-atmosphere experiment in Amazonia. In J. Cleveland, editor. The encyclopedia of Earth. Environmental Information Coalition, National Council for Science and the Environment, Washington, D.C., USA. [online] URL: http://www.eoearth. org/article/Large-Scale Biosphere-Atmosphere Experimentin_Amazonia

Lahsen, M. 2009. A science-policy interface in the global south: the politics of carbon sinks and science in Brazil. Climatic Change 97:339-372. http://dx.doi.org/10.1007/ $\underline{\mathrm{s} 10584-009-9610-6}$ 
Lahsen, M., and C. A. Nobre. 2007. Challenges of connecting international science and local level sustainability: the case of the Large-Scale Biosphere-Atmosphere Experiment in Amazonia. Environmental Science \& Policy 10(1):62-74. http://dx.doi.org/10.1016/j.envsci.2006.10.005

Lahsen, M., R. Sanchez-Rodriguez, P. Romero Lankao, P. Dube, R. Leemans, O. Gaffney, M. Mirza, P. Pinho, B. OsmanElasha, and M. Stafford-Smith. 2010. Impacts, adaptation and vulnerability to global environmental change: challenges and pathways for an action-oriented research agenda for middleand low-income countries. Current Opinion in Environmental Sustainability 2(5-6):364-374. http://dx.doi.org/10.1016/j. cosust.2010.10.009

McNie, E. C. 2007. Reconciling the supply of scientific information with user demands: an analysis of the problem and review of the literature. Environmental Science and Policy 10:17-38. http://dx.doi.org/10.1016/j.envsci.2006.10.004

Melillo, J., A. Rock, A. Abreu, J. Buizer, G. Gallopin, M. Gupta, and H. Virji. 2007. Report of the External Review Committee assessment of the Inter American Institute for Global Change Research. American Association for the Advancement of Science International Office, Washington, D.C., USA. [online] URL: http://www.aaas.org/programs/ centers/sd/aaas_IAIreport_0607.pdf

Miller, C. A. 1998. Extending assessment communities to developing countries. Environment and Natural Resources Program Discussion Paper E-98-15. John F. Kennedy School of Government, Harvard University, Cambridge, Massachusetts, USA. [online] URL: http://www.hks.harvard.edu/gea/pubs/ e-98-15.pdf

Misselhorne, A., P. Aggarwal, P. Ericksen, P. Gregory, L. Horn-Phathanothai, J. Ingram, and K. Wiebe. 2012. A vision for attaining food security. Current Opinion in Environmental Sustainability 4:7-17. http://dx.doi.org/10.1016/j.cosust.2012.01.008

Mitchell, R. B., W. C. Clark, D. W. Cash, and F. Alcock. 2006. Global environmental assessments: information, institutions, and influence. MIT Press, Cambridge, Massachusetts, USA.

Ostrom, E., J. Burger, C. B. Field, R. B. Norgaard, and D. Policansky. 1999. Revisiting the commons: local lessons, global challenges. Science 284:278-282. http://dx.doi. org/10.1126/science.284.5412.278

Otter, L. B., R. J. Scholes, P. Dowty, J. Privette, K. Caylor, S. Ringrose, M. Mukelabai, P. Frost, N. Hanan, O. Totolo, and E. M. Veenendaal. 2002. The Southern African Regional Science Initiative (SAFARI 2000): wet season campaigns. South African Journal of Science 98:131-137.
Prado, A. A. 2003. Biopirataria: Enquanto o Brasil não acorda. Jornal do Brasil Ecológico 12 August:20-22.

Reid, W. V., C. Bréchignac, and Y. T. Lee. 2009. Earth system research priorities. Science 325:245. http://dx.doi.org/10.1126/ science. 1178591

Rockström, J., W. Steffen, K. Noone, Å. Persson, F. S. Chapin III, E. F. Lambin, T. M. Lenton, M. Scheffer, C. Folke, H. J. Schellnhuber, B. Nykvist, C. A. de Wit, T. Hughes, S. van der Leeuw, H. Rodhe, S. Sörlin, P. K. Snyder, R. Costanza, U. Svedin, M. Falkenmark, L. Karlberg, R. W. Corell, V. J. Fabry, J. Hansen, B. Walker, D. Liverman, K. Richardson, P. Crutzen, and J. A. Foley. 2009. A safe operating space for humanity. Nature 461:472-475. http://dx.doi.org/10.1038/461472a

Rodó, X., M. Pascual, G. Fuchs, and A. S. G. Faruque. 2002. ENSO and cholera: a nonstationary link related to climate change? Proceedings of the National Academy of Sciences 99:12901-12906. http://dx.doi.org/10.1073/pnas.182203999

Sagar, A., and M. Kandlikar. 1997. Knowledge, rhetoric, and power: the international politics of climate change. Economic and Political Weekly 32:3139-3148.

Sagar, A. D., and S. D. VanDeveer. 2005. Capacity development for the environment: broadening the scope. Global Environmental Politics 5:14-22. http://dx.doi. org/10.1162/1526380054794844

Schor, T. 2008. Ciencia E Tecnologia: O Caso do Experimento de Grande Escala da Biosfera-Atmosfera na Amazônia (LBA). Annablume, Coleção Cidadania e Meio Ambiente, São Paulo, SP, Brasil.

Seabury, M. B. 2004. Scholarship about interdisciplinarity: some possibilities and guidelines. Issues in Integrative Studies 22:52-84.

Shugart, H. H. , S. A. Macko, P. Lesolle, T. A. Szuba, M. M. Mukelabai, P. Dowty, and R. J. Swap. 2004. The SAFARI 2000 - Kalahari Transect wet season campaign of year 2000. Global Change Biology 10:273-280. http://dx.doi.org/10.1111/ j.1365-2486.2004.00732.x

Snow, C. P. 1964. The two cultures: and a second look. Cambridge University Press, Cambridge, U.K.

Söderbaum, F. 2001. Networking and capacity building: the role of regional research networks in Africa. European Journal of Developmental Research 13:144-163. http://dx.doi. org $/ 10.1080 / 09578810108426798$

Stafford-Smith, M., O. Gaffney, L. Brito, E. Ostrom, and S. Seitzinger. 2012. Interconnected risks and solutions for a planet under pressure - overview and introduction. Current 
Opinion in Environmental Sustainability 4:3-6. http://dx.doi. org/10.1016/j.cosust.2012.01.011

Stake, R. E. 2000. Case studies. Pages 435-454 in N. K. Denzin and Y. S. Lincoln, editors. Handbook of qualitative research. Second edition. Sage, Thousand Oaks, California, USA.

Swap, R. J. 2008. The Inter-American Institute for Global Change Research: a resource for the Americas. Interciencia 33:402.

Swap, R. J., H. J. Annegarn, and L. Otter. 2002. Southern African Regional Science Initiative (SAFARI 2000) summary of science plan. South African Journal of Science 98:119-124.

Swap, R. J., H. J. Annegarn, J. T. Suttles, M. D. King, S. Platnick, J. L. Privette, and R. J. Scholes. 2003. Africa burning: a thematic analysis of the Southern African Regional Science Initiative (SAFARI 2000). Journal of Geophysical Research 108(D13):8465. http://dx.doi.org/10.1029/2003JD003747

Tomich, T. P., D. W. Timmer, S. J. Velarde, J. Alegre, V. Areskoug, D. W. Cash, A. Cattaneo, P. Ericksen, L. Joshi, J. Kasyoki, C. Legg, M. Locatelli, D. Murdiyarso, C. Palm, R. Porro, A. Rescia, A. Salazar-Vega, M. van Noordwijk, S. Weise, and D. White. 2007. Integrative science in practice: process perspectives from ASB, the partnership for the tropical forest margins. Agriculture, Ecosystems \& Environment 121:269-286. http://dx.doi.org/10.1016/j.agee.2006.12.015

Van Kerkhoff, L., and L. Lebel. 2006. Linking knowledge and action for sustainable development. Annual Review of Environment and Resources 31:445-477. http://dx.doi. org/10.1146/annurev.energy.31.102405.170850 